\title{
A Study on the Extent of Adoption of Biofertilizer by the Farmers in Etawah District of Uttar Pradesh, India
}

\author{
Ravindra Kumar* and Dipak Kumar Bose \\ Department of Agriculture Extension and Communication, SHUATS, Prayagraj, \\ Uttar Pradesh, India \\ *Corresponding author
}

\section{A B S T R A C T}

\section{Keywords}

Bio-fertilizer, Adoption, Etawah District

\section{Article Info}

Accepted:

20 October 2020

Available Online:

10 November 2020
The present study was carried out during 2018-20 in Jaswantnagar block of Etawah district. Five villages and 120 respondents were selected randomly and data were collected through personal interview method. Collected data were analyzed by using appropriate statistical methods for the interpretation at data. It was found that majority of respondents $(58.67 \%)$ had medium level of adoption followed by (33.34\%) had lowest level of adoption followed by (16.67\%) respondents had high level of adoption regarding Bio-fertilizer.

\section{Introduction}

India is an agricultural country. About seventy percent of the population depends on agriculture. One-third of the National income comes from agriculture. The development of agriculture has much to do with the economic welfare of our country. Bio-fertilizers are living micro-organisms of bacterial, fungal and algal origin. Their mode of action differs and can be applied alone or in combination. Simply biologically active products or microbial inoculants of bacteria, algae and fungi, which may help biological nitrogen fixation for the benefit of the plants, are defined as Bio-fertilizers. Bio-fertilizers add nutrients through the natural processes of nitrogen fixation, solubilising phosphorus, and stimulating plant growth through the synthesis of growth-promoting substances. Bio-fertilizers can be expected to reduce the use of chemical fertilizers and pesticides. The microorganisms in bio-fertilizers restore the soil's natural nutrient cycle and build soil organic matter. Through the use of biofertilizers, healthy plants can be grown, while enhancing the sustainability and the health of the soil. The main problem was low level of adoption regarding bio-fertilizer in present situation. Research Methodology The study was conducted in Jaswantnagar block of Etawah district of Uttar Pradesh state, which 
was purposively selected because there were more progressive farmers in Jaswantnagar block and farmers are trained by Krishi Vigyan Kendra, on Bio-fertilizers. The sample is comprised of 120 respondents from 5 villages which were selected randomly. The pre structured interview schedule used to collect the data related to adoption of biofertilizer. The information collected was scored, tabulated, computed and analyzed to have necessary interpretations.

\section{Materials and Methods}

Jaswantnagar block of Etawah district was purposively selected because there were more progressive farmers in Jaswantnagar block and farmers are trained on bio-fertilizer by the Krishi Vigyan Kendra. The samples are comprised of 120 respondents from 5 villages which were selected randomly. The pre structured interview schedule was used to collect the data related to adoption of biofertilizer. The entire data was transformed into normal score for tabulation. The independent variables as well as dependent variable were categorized as low, medium and high or the term applicable so far on the basis of score obtained. Keeping in view the objectives of the study and to draw logical conclusion the statistical test i.e. frequency, percentage, mean, standard deviation and correlation coefficient were used for analyzing and interpretation of the data.

\section{Results and Discussion}

The results obtained from present study as well as relevant discussion have been presented under following head.

\section{Socio-economic profile of the respondents}

In the present study independent attributes of the respondent have been considered. The data regarding socio-economic profile of the respondents were analyzed and their basic statistical values are presented in different tables 1-4.

Table. 1 Total number of respondents taken $n=120$

\begin{tabular}{|l|l|l|l|}
\hline SI.No. & Age in year & Frequency & Percentage \\
\hline 1. & Young $(20-35$ years $)$ & 35 & 29.16 \\
\hline 2. & Middle $(36-50)$ & 45 & 37.51 \\
\hline 3. & Old (>50 years ) & 40 & 33.33 \\
\hline SI.No. & Caste & Frequency & Percentage \\
\hline 1. & General & 35 & 29.16 \\
\hline 2. & OBC & 55 & 45.84 \\
\hline 3. & ST/SC & 30 & 25.00 \\
\hline SI.No. & Religion & Frequency & Percentage \\
\hline 1. & Hindu & 112 & 93.33 \\
\hline 2. & Muslim & 008 & 06.67 \\
\hline SI.No. & Education & Frequency & Percentage \\
\hline 1. & Illiterate & 35 & 29.16 \\
\hline 2. & Primary School & 41 & 34.17 \\
\hline 3. & High school & 20 & 16.67 \\
\hline 4. & Intermediate & 15 & 12.50 \\
\hline 5. & Graduate and above & 9 & 07.50 \\
\hline SI.No. & Land holding capacity & Frequency & Percentage \\
\hline 1. & Small size of land holding (Below one ha.) & 72 & 60.00 \\
\hline
\end{tabular}




\begin{tabular}{|l|l|l|l|}
\hline 2. & Medium size of land holding $(1-2$ ha. $)$ & 42 & 35.00 \\
\hline 3. & Large size of land holding (Above 3) & 06 & 05.00 \\
\hline SI.No. & Family Type & Frequency & Percentage \\
\hline $\mathbf{1 .}$ & Nuclear & 85 & 70.83 \\
\hline 2. & Joint & 35 & 29.17 \\
\hline Sl.No. & Annual Income & Frequency & Percentage \\
\hline $\mathbf{1 .}$ & Blow 1 lakh & 80 & 66.67 \\
\hline 2. & 1-2 lakh & 22 & 18.33 \\
\hline 3. & 2-3 lakh & 15 & 12.50 \\
\hline 4. & Above 3 lakh & 03 & 02.50 \\
\hline
\end{tabular}

Table.2 Adoption Behaviour of the wise distribution of respondents towards recommended practices of bio-fertilizer

\begin{tabular}{|c|c|c|c|c|}
\hline \multirow[t]{2}{*}{ S.N. } & \multirow[t]{2}{*}{ Recommended practices } & \multicolumn{3}{|c|}{ Answer } \\
\hline & & FA & PA & NA \\
\hline 1 & How much you are using in 1 hectare $(1 \mathrm{~kg}, 10 \mathrm{~kg})$ & $29(24.16 \%)$ & $46(38.34 \%)$ & $45(37.50 \%)$ \\
\hline 2. & Which bio fertilizer you are using & $25(20.84 \%)$ & $56(46.67 \%)$ & $39(32.50 \%)$ \\
\hline 3. & Different kind of fixing bio fertilizer & $17(14.16 \%)$ & $65(54.17 \%)$ & $38(31.67 \%)$ \\
\hline 4. & Use of composting bio-fertilizer & $45(37.50 \%)$ & $39(32.50 \%)$ & $40(33.34 \%)$ \\
\hline 5. & Advantages of Bio fertilizers & $37(30.84 \%)$ & $47(39.17 \%)$ & $46(38.34 \%)$ \\
\hline 6. & Use of different bio-fertilizer & $35(29.17 \%)$ & $65(54.17 \%)$ & $20(16.67 \%)$ \\
\hline 7. & Crops for which PSB recommended & $27(22.50 \%)$ & $54(45.00 \%)$ & $39(32.50 \%)$ \\
\hline 8. & Method of seed drying & $20(16.67 \%)$ & $69(57.50 \%)$ & $31(25.84 \%)$ \\
\hline 9. & Storage of bio fertilizer & $17(14.16 \%)$ & $65(54.17 \%)$ & $38(31.67 \%)$ \\
\hline
\end{tabular}

FA - Fully Adopted PA-Partially Adopted NA- Not Adopted

Table.3 Level of adoption of bio-fertilizer by the respondents

\begin{tabular}{|l|l|c|c|}
\hline S.NO. & Level of adoption & Frequency & Percentage \\
\hline 1. & Low(10-15) & 36 & 33.34 \\
\hline 2. & Medium (16-20) & 64 & 58.67 \\
\hline 3. & High $(21-25)$ & 20 & 16.67 \\
\hline & Total & 120 & 100.00 \\
\hline
\end{tabular}

Table.4 Relationship between the characteristic of farmers with adoption level

\begin{tabular}{|l|l|c|}
\hline S.No. & Variables & Correlation Coefficient Adoption \\
\hline $\mathbf{1}$ & Age & 0.0654 \\
\hline $\mathbf{2}$ & Education & $0.5123^{* *}$ \\
\hline $\mathbf{3}$ & Type of Family & 0.0142 \\
\hline $\mathbf{4}$ & Family Size & -0.0145 \\
\hline $\mathbf{5}$ & Land Holding & $0.6712^{* *}$ \\
\hline $\mathbf{6}$ & Social Participation & 0.0138 \\
\hline $\mathbf{7}$ & Annual income & $0.4876^{* *}$ \\
\hline $\mathbf{8}$ & Source of information & 0.1523 \\
\hline
\end{tabular}

** Significant at 0.01 level of probability

* Significant at 0.05 level of probability 


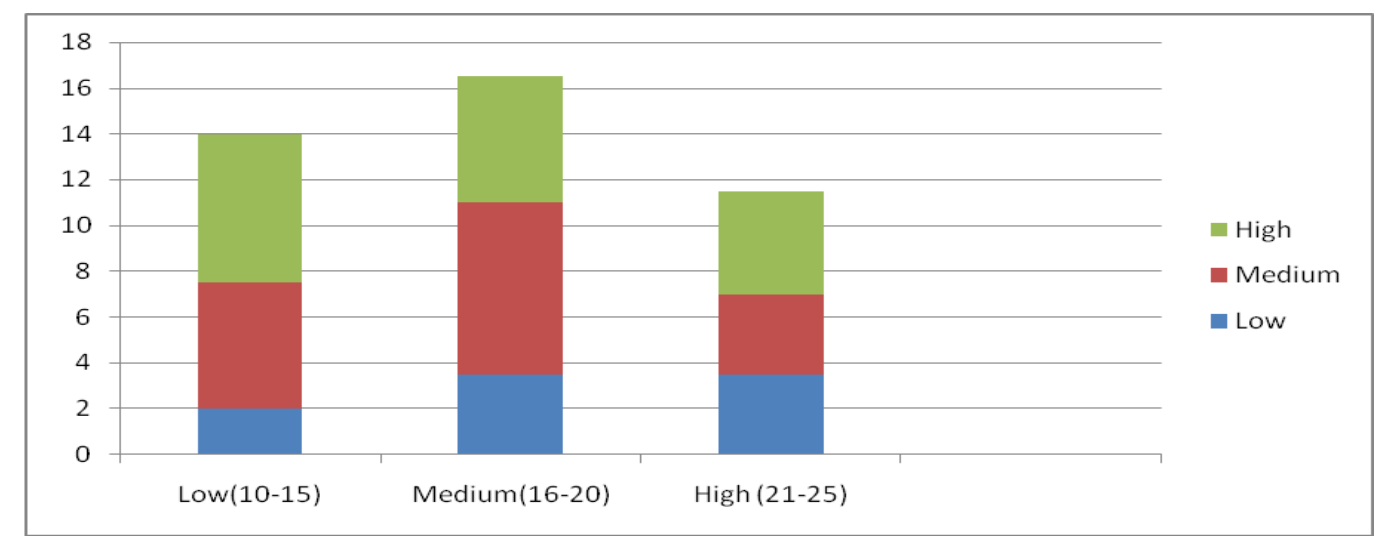

Table 2 shows that 38.34 per cent respondents were partially adopted the bio-fertilizers in their field followed by 37.50 per cent who were not adopted while 24.16 per cent responded were fully adopted. Above table stats that 46.67 per cent respondents were partially adopted the using of bio-fertilizers followed by 14.16 per cent who were fully adopted and not adopted respectively. From the above table it is clear that 33.34 per cent respondents were not adopted followed by 32.50 per cent who were partially adopted and rest 37.50 per cent respondents were fully adopted regarding use of fixing bio-fertilizer in their field. The above table shows that 16.67 per cent respondents were partial and 54.17 per cent respondents were not adopted while 37.50 per cent respondents who were fully adopted about the method of seed drying. Above table tells that 430.84 per cent respondents were fully adopted follow by 39.17 per cent and 38.34 per cent respondents who were fully adopted and not adopted regarding use of composting bio-fertilizer. In the above table it is mentioned that 29.17 per cent respondents were fully adopted while 54.17 per cent respondents partially adopted and rest 16.67 per cent respondents were not adopted about the recommended dose of composting bio-fertilizer. Above table shows that 32.50 per cent respondents were not adopted while 45 per cent and, 22.50 per cent respondents partially not and fully adopted regarding the recommended dose of PSB table states that 57.50 per cent respondent were partially adopted followed by 25.84 ,and 16.67 per cent respondents were not adopted and fully adopted the utilization of inoculated seed. Above table shows that 31.67 per cent respondents were not adopted about storage of bio-fertilizer while 54.17 per cent respondents were partially adopted followed by 14.16 per cent respondents who fully adopted. Similar finding is also reported by Rade et al., (1990), Nirmla et al., (1995).

The table 3 revealed that out of 8 different variables only 3 variables i.e. education, land holdings, annual income, was found to be positive and highly significantly correlated at 0.01 level of probability with the adoption level of the respondents. The other variables like age, type of family, and family size showed statistically non-significant relationship with socio-economic status of the respondents.

It was concluded that majority of the respondents were literate, belongs to nuclear family having small size of land holding and having annual income up to rupees one lakh. It was also observed that respondents have medium level of adoption of bio-fertilizer, the probable reason that they are belongs to medium level of socio-economic profile. Education, land holding, and annual income, was positively correlated with knowledge and adoption of bio-fertilizer. There for govt. should take be followed for more adoption of bio-fertilizer. 


\section{References}

Agnihotri, N., Bose D.K and Jahanara(2018) Adoption of sugarcane production technologies by its beneficiaries and non-beneficiaries through ATMA programme in Sitapur district of Uttar Pradesh. Journal of Pharmacognosy and Phytochemistry, 7(3): 3642-3644.

Dutt K. Sunil, rajeshwar jakkawad, rajendra.C. Sawant and S.B. Pawar (2016) Extent of Participation and Knowledge Level of the Beneficiaries About Various Aspects of bio-fertilizer and Benefits Availed. Journal of Trends in Biosciences 10(24).

Gordhariya Keyur Vallabhabhai (2011) Strategic analysis of farm school working under bio-fertilizer in south Gujarat.

Gonshetwad, B. M., Mokhale, S. U., Kapil Jat, Deshmukh A. N. (2015) Attitude of beneficiaries towards bio-fertilizer. Journal of Agriculture Update 2016 Vol.11 No.3 pp.298-300.

Mandal Pankaj Kumar and B. Jirli (2016) A Study on Socio Economic Profile of bio-fertilizer Respondents. International
Journal of Current Microbiology and Applied Sciences, Volume 7 Number 10, 2018

Motto Jehangir Muzaffar, Mushtaq Ahmad Dar, Rehana Jan, Zahoor Ahmad Shah and Rufaidah Mir(2018) A study on adoption about the recommended agricultural practices through biofertilizer by paddy growers in Budgam region of Kashmir. Journal of Pharmacognosy and Phytochemistry; 7(1): 45-49.

Sahu Bhedu Prasad, Chaturvedi, M.K. and Yadav Kedar Nath. (2011) Impact of bio-fertilizer on socio-economic status of tribal farmers. Agric. Update, 8(1\&2): 1-7. (2013).

Singh Krishna M., Burton E.Swanson, Awadhesh K. Jha and Mohar S. Meena (2014). Extension Reforms and Innovations in Technology Dissemination- bio-fertilizer Model in India.

Singh Krishna M. and Jha, Awadhesh, (2012) Innovative Approaches in Technology Dissemination: Experiences of biofertilizer Model in Bihar.

\section{How to cite this article:}

Ravindra Kumar and Dipak Kumar Bose. 2020. A Study on the Extent of Adoption of Biofertilizer by the Farmers in Etawah District of Uttar Pradesh. Int.J.Curr.Microbiol.App.Sci. 9(11): 2853-2857. doi: https://doi.org/10.20546/ijcmas.2020.911.344 